http://dx.doi.org/10.12775/szhf.2013.055

\author{
Aleksiej Nikołajewicz Kruglow
}

\title{
Bułhakow i Kant ${ }^{*}$
}

Jednym z kluczowych nawiązań rosyjskiej literatury do filozofii Kanta jest powieść Michaiła Afanasiewicza Bułhakowa (1891-1940) Mistrz i Małgorzata. Jednak ślady filozofii Kantowskiej niekiedy dostrzega się również we wcześniejszych utworach pisarza. Czasami też formułuje się paralele między odniesieniem do widoku rozgwieżdżonego nieba w Wojnie i pokoju Tołstoja i w Białej gwardii (1922-1924) Bułhakowa (zwłaszcza we wczesnych wariantach powieści). Źródłem inspiracji dla obu rosyjskich pisarzy w tej kwestii są końcowe fragmenty Krytyki praktycznego rozumu ${ }^{1}$. Zestawienie uwzględniające aspekt historyczny nie potwierdza się jednak w przypadku Tołstoja, a pośrednio również w przypadku Bułhakowa wywołuje ono wątpliwości. W każdym razie ten ostatni autor nadaje rozgwieżdżonemu niebu całkowicie inne znaczenie niż niemiecki filozof, chociaż zewnętrzne podobieństwo samych rozważań rzeczywiście tu zachodzi. O ile u Bułhakowa sklepienie niebieskie występuje w znaczeniu „zasłony Boga”, a gwiazdy zlęknione i wspaniałe zmuszają do namysłu nad ziemskim światem, o tyle u Kanta nabierają one przerażającego

\footnotetext{
* A. N. Kuglov, Kant i kantovskaâ filosofiâ v russkoj hudožestvennoj literature, Moskva 2012, s. 323-341 (tytuł artykuły pochodzi od tłumacza).

${ }^{1}$ Por. B. V. Sokolov, Bulgakov. Ėnciklopediâ. Personalii, prototipy, proizvedeniâ, druz'â i vragi, sem'â, Moskva 2005, s. 82, 366. [Chodzi w szczególności o rozdział zatytułowany „Istnienie Boga jako postulat czystego praktycznego rozumu”, por. I. Kant, Krytyka praktycznego rozumu, tłum. B. Bornstein, oprac. M. Żelazny, [w:] tenże, Dzieła zebrane, t. 3, Toruń 2012, s. 447 i nast.]

${ }^{2}$ M. A. Bulgakov, Belaâ gvardiâ (Sobr. soč.: V 5-ti t.) t. 1, Moskva 1989, s. 427.
} 
charakteru: czynią z człowieka całkowitą marność i już w żaden sposób nie symbolizują „ponadświatowego absolutu”.

Z jednej strony, musimy tu uwzględnić popularność Mistrza i Małgorzaty (1929-1940), a więc fakt, że powieść Bułhakowa zyskała szerokie kręgi czytelników, dla których ten utwór literacki funkcjonuje jako autorytatywne i dostępne źródło wiedzy o podstawowych tezach filozofii Kantowskiej. $\mathrm{Z}$ drugiej strony, w ostatnich dziesięcioleciach ukazała się znaczna liczba rozpraw z zakresu literaturoznawstwa poświęconych twórczości Bułhakowa, w których podjęto próby wyjaśnienia problematyki Kantowskiej w twórczości pisarza. Niestety, według mnie, najbardziej istotne pytania nadal pozostają bez odpowiedzi.

W już od dawna otoczonej legendą scenie, która rozgrywa się w powieści na Patriarszych Prudach Berlioz informuje Wolanda (przedstawianego $\mathrm{w}$ tym momencie jeszcze $\mathrm{w}$ charakterze nieznanego cudzoziemca) o tym, że razem ze swoim towarzyszem podróży, Bezdomnym, jest ateistą. Woland zwraca się do literata $\mathrm{z}$ następującym pytaniem (z lewej strony tabeli prezentowany jest tekst w ostatecznej redakcji, z prawej strony - jego wcześniejsza wersja, a mianowicie, jego trzecia redakcja):

- Ale pozwólcie, że was, panowie, zapytam - po chwili niespokojnej zadumy przemówił zagraniczny gość - co w takim razie począć z dowodami na istnienie Boga, których, jak wiadomo, istnieje dokładnie pięć?

- Niestety! - ze współczuciem odpowiedział Berlioz. - Żaden z tych dowodów nie ma najmniejszej wartości i ludzkość dawno odłożyła je ad acta. Przyzna pan chyba, że w kategoriach rozumu nie można przeprowadzić żadnego dowodu na istnienie Boga.

- Brawo! - zawołał cudzoziemiec. - Brawo! Pan dokładnie powtórzył pogląd nieokiełznanego staruszka Immanuela $\mathrm{w}$ tej materii. Ale zabawne, że stary najpierw doszczętnie rozprawił się z wszystkimi pięcioma dowodami, a następnie, jak gdyby szydząc z samego siebie, przeprowadził własny, szósty, dowód.
- Ale pozwólcie panowie, że zapytam, jak to jest $\mathrm{z}$ dowodami na istnienie, dowodami, których jest dokładnie pięć? - zwrócił się do niego cudzoziemiec $z$ bezgranicznym lękiem.

- Niestety - odpowiedział obywatel Berlioz, - żaden z tych dowodów niczego nie dowodzi. Już dawno odłożono je do lamusa. W dziedzinie rozumu żadnych dowodów istnienia Boga nie ma i być nie może.

- Brawo! - zawołał cudzoziemiec - brawo. W pełni powtórzył Pan myśl staruszka Immanuela w tej kwestii. On całkowicie obalił wszystkie pięć dowodów, ale potem, niech go diabli wezmą, jak gdyby kurom na śmiech, sklecił dowód własnego pomysłu! 
- Dowód Kanta - z subtelnym uśmiechem sprzeciwił się wykształcony redaktor - jest również nieprzekonujący. I nie na darmo Schiller powiada, że rozważania Kanta na ten temat mogą zadowolić tylko ludzi o duszach niewolników, a Strauss je po prostu wyśmiewa. [...]

- Najlepiej byłoby posłać tego Kanta na trzy lata na Sołowki za te jego dowody! nagle palnął nieoczekiwanie Iwan. [...]

Propozycja zesłania Kanta na Sołowki nie tylko jednak nie oszołomiła cudzoziem$\mathrm{ca}$, ale nawet wprawiła go w prawdziwy zachwyt.

- Otóż to! - zawołał [...]. - Tam jest jego miejsce! Przecież mówiłem mu wtedy, przy śniadaniu: „Jak pan tam, profesorze, sobie chce, ale wymyślił pan coś, co się kupy nie trzyma. Może to i mądre, ale zbyt skomplikowane. Wyśmieją pana”.

Berlioz wybałuszył oczy. „Przy śniadaniu... do Kanta! Co on plecie?” - pomyślał.

- Ale - mówił dalej cudzoziemiec do poety, nie speszony zdumieniem Berlioza - zesłanie go na Sołowki jest niemożliwe z tej przyczyny, że Kant już od stu z górą lat przebywa w miejscowościach znacznie bardziej odległych niż Sołowki i wydobycie go stamtąd jest zupełnie niemożliwe, zapewniam pana.

- A szkoda! - wypowiedział się agresywny poeta.

- Ja również żałuję...*
- Dowód Kanta, - powiedział wykształcony Berlioz, uśmiechając się przy tym subtelnie - także nie jest przekonujący, i nie na próżno Schiller powiedział, że dowodzenie Kanta jest przydatne dla niewolników [...]

- Właśnie! Właśnie! - przemówił entuzjastycznie, - tam jest jego miejsce. Mówiłem mu: wymyśliłeś bzdurę, Immanuelu. [...]

- Ale, - kontynuował nieznajomy, wsadzić go, niestety, już nie można z dwóch przyczyn: po pierwsze, jest zagranicznym poddanynym, a po drugie, umarł.

* M. A. Bulgakov, Master i Margarita (Sobr. soč.: V 5-ti t.) t. 5, Moskva 1990, s. 13-14 [cytuję według wyd. pol.: M. Bułhakow, Mistrz i Małgorzata, tłum. I. Lewandowska i W. Dąbrowski, Warszawa 1994, s. 17]. 
Należy dodać, że w jeszcze wcześniejszych wariantach (z lat 1928-1929) Bułhakow jeden z rozdziałów zatytułował Dowód szósty, rozumiejąc przez to dowód sformułowany przez Wolanda. W ostatecznej redakcji znalazł się rozdział Dowód siódmy ${ }^{3}$, w którym mowa jest o tym samym dowodzie.

Podczas lektury tekstu powieści pojawia się szereg pytań ${ }^{4}$. Cóż to za pięć dowodów istnienia Boga, o których rozmawia się tak apodyktycznie jako o czymś wszystkim dobrze znanym? Czy rzeczywiście Kant twierdził, że w dziedzinie rozumu dowód istnienia Boga nie jest możliwy do przeprowadzenia? Czy Kant obalił pięć sławnych dowodów istnienia Boga? Co należy rozumieć przez „szósty dowód” Kanta? Z czym wiąże się zamęt wokół „szóstego dowodu” w różnych redakcjach powieści? Jakich „niewolników” miał w związku z tym na myśli Schiller? I co takiego śmieszyło Straussa? ${ }^{5}$ Dlaczego Kant został tu nazwany "nieokiełznanym staruszkiem”, albo „staruszkiem”? Jak przedstawia się sprawa z rozmową podczas śniadania z Kantem? No i wreszcie, czy rzeczywiście postać Mistrza ze wstępnych rozdziałów powieści nosi ostatecznie jakieś Kantowskie rysy, jakie dostrzegamy w następującej wypowiedzi Wolanda: „Będą płonąć świece, usłyszysz kwartety, pokoje w domu będą pachnieć jabłkami. W pudrowanym warkoczu, w staromodnym znoszonym kaftanie, stukając laską, będziesz chodził, spacerował i myślał"'?

Część z tych problemów była już omawiana przez znawców twórczości Bułhakowa. Dzięki wiedzy o tym, że podczas pracy Bułhakow intensywnie korzystał ze słownika encyklopedycznego Brockhausa i Efrona ${ }^{7}$, udało się ustalić źródło sformułowań, które pisarz niemal dosłownie wkłada w usta Berlioz w rozmowie z Wolandem. Chodzi o słownikowy artykuł Bóg, zredagowany przez absolwenta Moskiewskiej Akademii Duchownej Pawła Pietrowicza Wasiljewa (ur. w 1845 roku). Wasiljew początkowo wyróżnia w swym

${ }^{3}$ Por. wyd. pol. s. 52 i nast.

${ }^{4}$ Pytania typu „czy Woland ma władzę nad zmarłym Kantem?”, podobnie jak pytanie „czy filozof zasłużył na zesłanie do Sołowek?”, są bez wątpienia bardzo interesujące, jednak nie mają związku z tematem niniejszych rozważań.

${ }^{5}$ [Na ten temat por. T. Kupś, Filozofia religii Immanuela Kanta, Toruń 2008, s. 11 i nast.]

${ }^{6}$ M. A. Bulgakov, Master i Margarita. Černovye glavy romana, dopisannyei perepisannye v 1934-1936 godah (Sobr. soč.: V 10-ti t.), t. 7, Moskva 1999, s. 724.

${ }^{7}$ Por. M. O. Čudakova, Arhiv M. A. Bulgakova. Materialy dlâ tvorčeskoj biografiipisatelâ (Zapiski otdela rukopisej Gosudarstvennoj biblioteki im. V. I. Lenina.Vyp. 37), Moskva 1976, s. 72-73. [Chodzi o pierwszą rosyjską encyklopedię powszechną, wydaną w 82 tomach (i 4 tomach uzupełnień) w latach 1890-1907. Wydawnictwo to było owocem współpracy lipskiego wydawnictwa Brockhausa i petersburskiego wydawcy Ilii Abramowicza Efrona.] 
artykule cztery typy dowodów „istnienia Boga”: dowody kosmologiczne i teleologiczne (opierające się na analizie zewnętrznego doświadczenia), a także dowody ontologiczne i moralne (które zakładają jako podstawę doświadczenie wewnętrzne). Do wymienionych czterech typów Wasiljew dodaje jeszcze piąty dowód, nazywając go dowodem historycznym, a który oparty jest na fakcie, że wszystkie znane ludy wyznają jakąś religię. Jednakże dowód historyczny, ze wszystkich wymienionych, według Wasiljewa nie jest dowodem ścisłym, zdolnym osiągnąć wymaganą od dowodu powszechność i konieczność ${ }^{8}$. Po omówieniu kosmologicznego, teleologicznego i ontologicznego dowodu, zauważa: „Wszystkie wymienione dowody znalazły surowego i nie całkiem sprawiedliwego krytyka w osobie Kanta, który nie tylko neguje siłę i skuteczność tych dowodów, ale również uznaje za niemożliwe znalezienie jakiegokolwiek dowodu istnienia Boga w dziedzinie czystego rozumu. Jednakże niewiara nie zdołała długo nacieszyć się niszczycielską pracą Kanta. Przecząc sile i znaczeniu wszystkich dowodów, sformułował nowy, własny dowód istnienia Boga. Jest on według niego oparty na idei moralnego obowiązku i na potrzebie - ze strony praktycznego rozumu - [istnienia] najwyższego moralnego władcy świata, niezbędnego do urzeczywistnienia moralnego prawa, a więc do ustanowienia harmonii między doskonałą cnotą i szczęściem człowieka. W naszym sumieniu istnieje bezwarunkowy nakaz moralnego prawa, którego sami nie tworzymy i który nie powstaje w wyniku wzajemnego porozumienia się ludzi między sobą w stanie społecznego dobrobytu. Nierozerwalna więź łącząca prawo moralne $\mathrm{z}$ istotą naszego ducha i jego niezależność (prawa) od naszej samowoli prowadzą do wniosku, że jego sprawcą może być jakiś najwyższy prawodawca moralnego świata" Wasiljew uważa, że Kant w swoim dowodzie stwierdza istnienie osobowego Boga, co wywołało ostrą krytykę: „Schiller mówi, że Kant głosi moralność, mającą zastosowanie tylko dla niewolników. Strauss kpiąco zauważa, że Kant do swojego systemu, co było niezgodne z duchem teizmu, dobudował pokoik, by umieścić w nim Boga" ${ }^{\prime 10}$.

Według I. Z. Biełobrowcewej i S. K. Kuljusa, pięć dowodów istnienia Boga w powieści Bułhakowa pochodzi z artykułu Wasiljewa, szósty dowód został przypisany Kantowi po śmierci, natomiast w roli siódmego występuje dowód

\footnotetext{
${ }^{8}$ Por. P. P. Vasil'ev, Bog' (ÈS / Izd. F. A. Brokgauz, I. A. Efron), t. 7 (polutom), Sankt-Peterburg 1891, s. 207.

9 Tamże, s. 207-208.

10 Tamże, s. 208.
} 
życiowy w związku z przepowiednią śmierci Bierlioza za niewiarę w diabła ${ }^{11}$. M. O. Czudakowa wyjaśnia różnice w interpretacji szóstego dowodu tym, że $\mathrm{w}$ pierwszej redakcji powieści była już mowa o pięciu dowodach istnienia Boga, ale jeszcze nie chodziło o dowód Kanta. W ten sposób dowód Wolanda okazywał się szóstym dowodem ${ }^{12}$. W Булгаковской энииклопедии odwrotnie: twierdzi się, że ponieważ w pierwszej redakcji powieści dowód Wolanda został określony jako dowód szósty, więc dowód Kantowski został nazwany piątym dowodem. Brakujący dowód został jakoby przez pisarza odnaleziony w dziele Kanta zatytułowanym Der einzig mögliche Beweisgrund zu einer Demonstration des Daseyns Gottes ${ }^{13}$, a dokładnie, dowód „logiczny”, także obalony przez filozofa tak samo, jak dowód historyczny, kosmologiczny, teleologiczny i ontologiczny ${ }^{14}$.

Wspomniany artykuł ze słownika encyklopedycznego wywołuje wiele pytań i uwag. Trudno w ogóle zrozumieć, dlaczego przynajmniej jedna trzecia artykułu o Bogu poświęcona została dowodom jego istnienia. Przy całym szacunku do Wasiljewa, nie był on w Rosji tego czasu klasycznym autorem piszącym na temat teologii. W wiarygodnej pracy profesora Moskiewskiej Akademii Duchownej Wiktora Dmitrijewicza Kudriawcewa-Płatonowa (1828-1891), od którego Wasiljew, najprawdopodobniej, zapożyczył własne poglądy, wyróżnia się sześć dowodach istnienia Boga: kosmologiczny, teleologiczny, ontologiczny, psychologiczny, historyczny i moralny ${ }^{15}$. Jeśli więc można mówić o klasycznych pięciu dowodów, to na myśl przychodzi słynne "pięć dróg” (quinque viae) z Sumy teologii Tomasza z Akwinu (ok. 1225-1274), a z pewnością nie lista dowodach podanych przez Wasiljewa.

Ale niezależnie od tego, na ile udany okazał się artykuł Wasiljewa, a także nie uwzględniając motywów, jakie skłoniły Bułhakowa, by odnieść się do treści tego artykułu w swojej powieści, w obronie autora artykułu ze słownika encyklopedycznego, należy powiedzieć, że on nie twierdził, jakoby Kant

${ }^{11}$ Por. I. Z. Belobrovceva, S. K. Kul'ûs, Roman M. Bulgakova «Master i Margarita». Kommentarij, Tallin 2006, s. 146-147.

${ }^{12}$ Por. M. O. Čudakova, Arhiv M. A. Bulgakova. Materialy dlâ tvorčeskoj biografiipisatelâ, s. 66-67; M. O. Čudakova, Opyt rekonstrukcii teksta M. A. Bulgakova (Pamâtniki kul'tury. Novye otkrytiâ. Pis'mennost'. Iskusstvo. Arheologiâ. Ežegodnik 1977), Moskva 1977, s. 94-95. ${ }^{13}$ [Wyd. pol. I. Kant, Jedyna możliwa podstawa dowodu na istnienie Boga, tłum. Translatorium Filozofii Niemieckiej Instytutu Filozofii UMK, [w:] tenże, Dzieła zebrane, t. 1, Toruń 2010.]

${ }^{14}$ Por. B. V. Sokolov, Bulgakov. Ėnciklopediâ, s. 366, 713-714; I. Z. Belobrovceva, S. K. Kul'ûs, Roman M. Bulgakova «Master i Margarita», s. 146-147.

${ }^{15}$ V. D. Kudrâvcev, Načal'nye osnovaniâ filosofii, Sergiev Posad 1915, s. 151-183. 
obalił cztery albo pięć dowodów. W całkowitej zgodności z tekstem źródłowym - a w tym przypadku jest to Krytyka czystego rozumu - Wasiljew uczciwie stwierdza, że Kant odrzucił kosmologiczny, teleologiczny (albo fizyko-teologiczny) i ontologiczny dowód. Dowodu historycznego, który właściwie czasami włącza się w obręb dowodu moralnego ${ }^{16}$, filozof królewiecki wcale nie rozpatrywał ze zrozumiałych względów; nawet Wasiljew usuwa go z liczby dowodów $\mathrm{w}$ ścisłym sensie tego słowa ${ }^{17}$. Nie dysponuję żadnymi świadectwami ani dokumentami, które potwierdzałyby, że Bułhakow odnosił się do Kantowskiego traktatu z 1763 roku podczas pracy nad swoją powieścią. Jednakże twierdzenie o obecności w pierwszej [redakcji powieści] „logicznego” dowodu jest po prostu nonsensem, choć z zupełnie innych powodów. Po pierwsze, niezależnie od tego jak swobodnie zostałby dokonany poprzedni podział na pięć dowodów, jasno wynika, że na przykład dowód kosmologiczny nie jest dowodem teleologicznym i na odwrót. Co jednak się stanie, jeśli na ich miejsce podstawimy dowód „logiczny”? Czy nie oznacza to, że ontologiczny albo kosmologiczny dowód nie są w istocie logiczne? A jeśli rzeczywiście nie są, to na czym polega logiczność dowodu „logicznego"? Po drugie, podobny zwrot (tzn. „dowód logiczny”) nie występuje ani razu w całym tekście Kantowskiego traktatu ${ }^{18}$. U Kanta nie ma takiej klasy dowodów istnienia Boga ani we wczesnym traktacie [z 1763 roku], ani w Krytyce czystego rozumu. Jak wobec tego nieobecny dowód może zostać zbity, o tym nic mi nie wiadomo ${ }^{19}$. Po trzecie, przy całym godnym pochwały

${ }^{16}$ Por. Gottesbeweis, moralischer, [w:] Historisches Wörterbuch der Philosophie, hrsg. von J. Ritter, K. Gründer, Bd. 3, Basel 1974, szp. 832-833.

${ }^{17}$ „Tak więc są cztery dowody istnienia Boga...”. Vasil'ev, P. P., Bog', s. 207.

${ }^{18}$ Jest tylko jedna fraza, która z grubsza przypomina brzmienie poszukiwanego zwrotu „doskonałe logicznie dowody" (Jedyna możliwa podstawa... AA II 87), ale i ona mówi nie o szczególnym rodzaju „logicznego" dowodu, ale o tym, że wśród wszystkich rodzajów dowodów można wyróżnić rzeczywiście prawdziwe dowody, albo inaczej „logicznie poprawne” dowody. W gruncie rzeczy mogą one być trudne do zrozumienia przez prostego człowieka, lecz ten problem Kant pominął.

${ }^{19} \mathrm{O}$ tym, że Bulgakovskaâ ènciklopediâ jest w istocie niesolidną kompilacją - jak zresztą również inne pseudohistoryczne „badania” jej autora - widać choćby na podstawie liczby faktycznych błędów, które występują zaledwie na kilku stronach tekstu (por. Sokolov, B. V., Bulgakov. Ėnciklopediâ, s. 338, 365-366, 713). Kant rozpoczął edukację w „szkole” nie w roku 1733, ale już w roku 1730; po ukończeniu wstępnej nauki w 1732 roku wstąpił do gimnazjum, znanego jako Kolegium Fridericianum. Studentem Kant został nie „po ukończeniu szkoły”, ale po zakończeniu nauki we wspomnianym gimnazjum. Żadne dokumenty nie potwierdzają tego, że „Został studentem wydziału teologicznego”, dotychczas tego nie zweryfikowano (przekonanie Borowskiego obalił sam Kant), a autor nie powołuje się na żadne nowe archiwalia. „Profeso- 
zainteresowaniu autora wobec Kantowskiego traktatu z 1763 roku, wygląda on bardzo dziwnie wyrwany z kontekstu następującej później Krytyki czystego rozumu; pewne wczesne tezy Kanta przejdą bowiem do niej dosłownie, inne zostaną rozwinięte i skorygowane. W każdym razie ostatnie słowo "profesora” w sprawie krytyki teologii racjonalnej - a, jak się wydaje właśnie o nim, a nie o magistrze Kancie, mowa jest w powieści Bułhakowa - zawiera się w Krytyce czystego rozumu ${ }^{20}$. W Mistrzu i Małgorzacie czytamy o obaleniu przez Kanta dowodów istnienia Boga, a w jaki sposób można byłoby o tym mówić, nie biorąc w rachubę Krytyki czystego rozumu? W niej właśnie, czarno na białym, zostało napisane, że „[z] rozumu spekulatywnego mogą wypływać tylko trzy rodzaje dowodów na istnienie [Dasein] Boga”: „Pierwszy dowód jest fizyko-teologiczny, drugi kosmologiczny, trzeci ontologiczny. Nie ma ich więcej i być nie może"21.

Nieporozumienia związane $\mathrm{z}$ filozofią Kantowską w powieści Bułhakowa zaczynają się zatem od postawienia tezy, że Kant obalił „dokładnie” pięć dowodów. Można byłoby powiedzieć, że Bułhakow rozmyślnie pragnął pokazać bezkrytyczność Berlioza za pomocą tych przysłowiowych pięciu dowodów ${ }^{22}$, ale tylko w odniesieniu do nich Woland mówi: ,jak wiadomo"; Berlioz natomiast jedynie podtrzymuje rozpoczęty temat. Trudno zaś prze-

rem nadzwyczajnym” Kant nigdy nie był. Dysertacja z 1770 roku była albo trzecią dysertacją „habilitacyjną", albo drugą, ale po pominiętej Monadologii fizycznej. Innymi słowy, Kant obronił dysertację O ogniu (1755) wymaganą na stopień doktora, następnie dysertację uprawniającą do nauczania na uniwersytecie: Nowe wyjaśnienie pierwszych zasad poznania metafizycznego (1755), a w końcu dwie dysertacje będące podstawą otrzymania profesury: Monadologia fizyczna (1756) oraz O formie i zasadach świata zmystowego i intelligibilnego (1770). Kant pracował w bibliotece zamku królewskiego w Królewcu, ale nie był „pomocnikiem bibliotekarza uniwersyteckiego". Imperatyw kategoryczny Kanta to z pewnością nie złota zasada moralności, która znana jest pod postacią „nie czyń drugiemu, co tobie niemiłe”.

${ }^{20}$ [Autor podkreśla w ten sposób różnicę czasu dzielącą publikację Jedynej możliwej podstawy dowodu na istnienie Boga (gdy Kant był jeszcze magistrem) i Krytyki czystego rozumu (której autor piastował już stanowisko profesora).]

${ }^{21} \mathrm{KrV}$ : B 618, 619/A 590, 591 [cytuję według: I. Kant, Krytyka czystego rozumu, tłum. M. Żelazny, [w:] tenże, Dzieła zebrane, t. 2, Toruń 2013]. Kant jako pierwszy nazywał dowód wywodzący się od Anzelma z Canterbury dowodem „ontologicznym”.

${ }^{22}$ Przy okazji, mało przekonująco wyglądają próby pisarza zmierzające do tego, by się zdystansować od stanowiska Berlioza w sprawie dowodów istnienia Boga, gdy uwzględnimy fakt, że ojciec pisarza, Afanasij Iwanowicz Bułhakow (1859-1907), był profesorem Kijowskiej Akademii Duchownej i należał do znawców wyznań protestanckich. Oprócz oczywistej wątpliwości co do przekazywania wiedzy z ojca na syna należy uwzględnić następujące przypuszczenie. Wasiljew także był specjalistą w sprawach protestantyzmu, był absolwentem 
czyć temu, że Kant ze swego punktu widzenia rzeczywiście wykazywał bezpodstawność wszystkich dowodów istnienia Boga w sferze spekulatywnej, albo teoretycznej: „Utrzymuję zatem, że wszelkie próby wyłącznie spekulatywnego zastosowania rozumu w odniesieniu do teologii są zupełnie bezcelowe, w aspekcie zaś swej wewnętrznej właściwości nijakie i nic niewarte. Natomiast podstawowe zasady [Principien] zastosowania go do przyrody nie prowadzą do żadnej teologii. [...] rozum w swym użyciu wyłącznie spekulatywnym bynajmniej nie nadaje się do tak wielkiego zamierzenia, tj. do tego, by dotrzeć do istnienia [Dasein] naczelnej istoty..." ${ }^{23}$.

Kolejna niedorzeczność mająca długą historię opiera się na twierdzeniu wypowiedzianym w powieści ustami Wolanda, o tym, jakoby Kant „jak gdyby szydząc z samego siebie” albo "kurom na śmiech” wymyślił własny, "szósty” dowód istnienia Boga. Po pierwsze, przytoczona numeracja nie ma żadnego związku z Kantem. Po drugie, nawet jeśli tymczasowo zgodzimy się, że w tekstach Kanta mowa jest o jakimś „dowodzie moralnym” - niezależnie od tego, co właściwie przez niego by rozumiano - „własnego pomysłu”, to dowodem on u filozofa niemieckiego na pewno nie jest. W tym celu wcale nie trzeba studiować opracowań, wystarczy bowiem posłuchać samego Kanta: „Ten moralny [moralischen] dowód nie jest jakąś nowo wynalezioną racją dowodową, ale tak czy inaczej [racją] w nowy sposób rozwiniętą. Dowód ten tkwił bowiem we władzy ludzkiego rozumu jeszcze przed najwcześniejszymi zarodkami jej rozwoju, zaś wraz z postępem kultury był tylko rozwijany"24.

Szeroką popularność wyobrażenia o niedorzeczności, jaka rzekomo zachodzi w filozofii Kantowskiej, a polega na tym, że Kant najpierw obalił wszystkie dowody istnienia Boga, a potem wymyślił własny dowód, zawdzięczamy przede wszystkim Heinemu: „Immanuel Kant kroczył aż do tego miejsca ścieżką nieubłaganego filozofa, przypuścił szturm na niebiosa i wyciął w pień całą ich załogę. Oto Pan świata pływa, niedowiedziony, we własnej krwi, nie ma już wszechogarniającego miłosierdzia, ojcowskiej dobroci, czekającej w zaświatach nagrody za ziemską wstrzemięźliwość, nieśmiertelność duszy wydaje ostatnie tchnienie - słychać rzężenie i jęki - zaś stary Lampe stoi obok, trzymając pod pachą swój parasol, niczym zasmucony widz, a pot i łzy ściekają mu po twarzy. I oto ulituje się nad nim Immanuel Kant i dowie-

akademii duchownej i wykładowcą seminarium. Nie uchroniło go to jednak przed błędnym i powierzchownym traktowaniem filozofii religii Kanta.

${ }^{23} \mathrm{KrV}$ : B 664, 667/A 636, 639.

${ }^{24} \mathrm{KU}: \mathrm{V} 458, \$ 88$ [cytuję według niepublikowanego przekładu: I. Kant, Krytyka władzy sqdzenia, tłum. M. Żelazny, [w:] tenże, Dzieła zebrane, t. 4, Toruń 2014]. 
dzie, iż jest nie tylko wielkim filozofem, ale i wielkiej dobroci człowiekiem, namyśli się i na wpół dobrotliwie, na wpół ironicznie powie: «Stary Lampe musi mieć jakiegoś Boga, inaczej nie będzie biedak szczęśliwy - człowiek zaś winien być na tej ziemi szczęśliwy - tak powiada rozum praktyczny - cóż, jeśli o mnie chodzi - niech rozum praktyczny zagwarantuje istnienie Boga». W następstwie tego argumentu wprowadził Kant rozróżnienie pomiędzy rozumem teoretycznym i praktycznym, za pomocą tego ostatniego zaś, niczym czarodziejskiej różdżki, ożywił na powrót trupa deizmu, uśmierconego przez rozum teoretyczny. - Czy być może, iż tej rezurekcji dokonał Kant nie tylko przez wzgląd na starego Lampe, ale i na policję" 25 . W tym samym tonie utrzymany jest także artykuł Wasiljewa.

Nawet jeśli weźmiemy poprawkę na wylewającą się żółć sarkazmu Heinego i jawną przesadę, w jaką popada, że „bzdurę" wymyślił nie tyle Immanuel, co raczej Henryk, to trudno mi zrozumieć upodobanie do dowodów istnienia Boga występujące u intelektualistów, a tym bardziej u prostych ludzi. Na czym w ogóle polega cel tego rodzaju dowodów? Czy emerytowany żołnierz Marcin Lampe, jeśli rzeczywiście był człowiekiem wierzącym, to czy był takim dzięki temu, że o istnieniu Boga przekonał go dowód ontologiczny? I czyż właśnie dla nieszczęśliwego Lampego Kantowska krytyka tego dowodu przedstawiała jakiekolwiek egzystencjalne niebezpieczeństwo, bo burzyła jego wiarę w Boga? To, co wiadomo o Lampem z zasługujących na zaufanie biografii Kanta, skłania nas raczej do powątpiewania w to, że był on zdolny zrozumieć, na czym w ogóle ten dowód polega ${ }^{26}$. Sprawia on bowiem pewną trudność nawet studentom wydziałów filozoficznych ${ }^{27}$. W naturalny sposób powstaje pragnienie zrozumienia, w jaki sposób chrześcijaństwo w ogóle

${ }^{25}$ Być może tu należy szukać jednego ze źródeł rozważań rosyjskich pisarzy i poetów o „policyjności” filozofii Kantowskiej. [cyt. wg wyd. pol.: H. Heine, $Z$ dziejów religii i filozofii w Niemczech, tłum. T. Zatorski, Kraków 1997, s. 122].

${ }^{26}$ Nawet w szczegółach opis Heinego wiele traci z powodu nieścisłości. Motyw parasola w rękach Lampego zapożyczony został przez Heinego nie z biograficznych materiałów bezpośrednio dotyczących życia Kanta, w których, o ile mi wiadomo, nie występuje w ogóle, ale z wydanego kilka lat przed rozprawą Heinego utworu literackiego zatytułowanego Urwany guzik, autorstwa urodzonego w Królewcu Johanna Carla Augusta Lewalda (1792-1871). Por.: A. von Lewald, Der abgerissene Knopf. Novellen, t. 2, Hamburg 1831, s. 6-7. Pod wpływem Heinego ów „parasol” został, prawdopodobnie, przekazany dalej; por. na przykład: N. Â. Ėjdel'man, Apostol Sergej, s. 21.

${ }^{27}$ Sam Kant o dowodzie ontologicznym i kosmologicznym pisał w następujący sposób: „Należy tylko zaznaczyć, że dowody takie, mimo że można by ich bronić za pomocą wszelkiego rodzaju subtelności dialektycznych, nie mogą nigdy mieć zasięgu szerszego aniżeli akademicki 
zdołało przetrwać pierwsze tysiąclecie do czasu, gdy Anzelm z Cantenbury (1033-1109) w swoim Proslogionie sformułował dowód, który Kant w XVIII wieku nazwał dowodem ontologicznym?

Patetyczny styl Heinego nie jest w stanie ukryć przesłanek leżących u podstaw jego argumentacji: twierdzenie o obaleniu dowodów istnienia Boga przez Kanta zastępuje twierdzeniem o zamordowaniu, a następnie wskrzeszeniu Boga przez filozofa, sprawiając wrażenie, jak gdyby były to tezy identyczne. Jeśli pierwsza teza jest jednym z podstawowych twierdzeń Krytyki czystego ro$z u m u$, to druga stanowi wymysł Heinego, a także jego licznych zwolenników. Odwrócenie polega także na wyobrażeniu, jakoby Kant najpierw obalił wszystkie dowody (Krytyka czystego rozumu), a zaraz potem z litości wymyślił własne (chodzi o Boga jako postulat czystego praktycznego rozumu w Krytyce praktycznego rozumu, chociaż terminologicznie "dowód moralny” formułowany jest tylko w Krytyce władzy sadzenia). Na tych samych stronach, na których Kant w Krytyce czystego rozumu mówi o niemożliwości dowodów istnienia Boga $\mathrm{w}$ dziedzinie filozofii spekulatywnej, wypowiada się także o prawach moralnych, które jako jedyne mogą doprowadzić do teologii ${ }^{28}$. Co więcej, w krótkim fragmencie Kant wyłożył idee przyszłej Krytyki praktycznego rozumu jeszcze w Krytyce czystego rozumu, odpowiadając w „Metodologii transcendentalnej” na swoje słynne pytanie „Czego mam się spodziewać?”29. Zasadnicze zmiany, których on jednak później dokonał w Krytyce praktycznego rozumu (1788), polegają na tym, że argumentacja w odniesieniu do postulatów praktycznego rozumu (wolności, nieśmiertelności duszy i istnienia Boga) wygląda u niego inaczej w wersji z 1781 roku, respektuje bowiem autonomię ludzkiej woli, ogłoszoną w Ugruntowaniu metafizyki moralności (1785). Właściwie więc, jeśli Kant rzeczywiście dla Lampego wymyśliłby podział na rozum praktyczny i teoretyczny, przeczyłoby to innym twierdzeniom Heinego, bo wykazywałoby, że jeszcze przed napisaniem Krytyki czystego ro$z u m u$, a nie po niej i nie z litości, jasno już dostrzegał całość tego obrazu. Inaczej trudno byłoby wyjaśnić tytuły pierwszych dwóch Krytyk Kanta.

Niezależnie od tego jak bardzo dziwne wydawałoby się to Heinemu i jego zwolennikom, Kant uważał, że swoją krytyką (a więc obalając dowody istnienia Boga) wyświadczył religii przysługę, bo udało mu się „...podciąć

i nie mogą przeniknąć do społeczeństwa, ani wywrzeć najmniejszego wpływu na sam zdrowy rozsądek", KU: V 476.

${ }^{28}$ Por. KrV: B 664, 669/A 636, 641.

${ }^{29}$ Por. KrV: B 832-847/A 804-819. 
korzenie materializmu, fatalizmu, ateizmu, wolnomyślnej nie wiary, urojeń i zabobonu..." ${ }^{30}$. Wasiljew przypuszcza, że „niewiara” nie była w stanie zadowolić się krytyką sformułowaną przez Kanta z powodu jego własnego dowodu. Kant był przekonany, że niewiara rzeczywiście nie może znaleźć pociechy w jego Krytyce czystego rozumu, ale z zupełnie innego powodu. Chociaż zakładał, że „kiedyś wynajdzie się jeszcze bardziej ewidentną demonstrację" ${ }^{31}$ istnienia Boga i życia pozagrobowego, to jednak zarazem uważał, iż jest „apodyktycznie pewny, że nigdy nie pojawi się żaden człowiek, który z najmniejszym choćby prawdopodobieństwem, a cóż dopiero dogmatycznie, będzie w stanie udowodnić c o ś p r z e c i w n e g o" ${ }^{32}$. Innymi słowy, „transcendentalna krytyka, odkrywszy mi wszelkie zasoby naszego czystego rozumu, przekonała mnie w pełni, że tak samo jak nie wystarcza on zupełnie do wygłaszania na tym polu sądów twierdzących, tak też, a nawet tym bardziej, nie będzie w stanie w żadnej mierze twierdzeniom tym zaprzeczyć"33. Jeśli jednak w pierwszym przypadku, teoretycznemu albo spekulatywnemu rozumowi, może przyjść z pomocą rozum praktyczny ze swoim podmiotowym wsparciem, to w drugim przypadku w ogóle nie można na to liczyć.

Właśnie ze wspomnianą pomocą praktycznego rozumu związane jest również to, że Kant nie zbudował, lecz sformułował (według mnie, bardzo niefortunnie) coś takiego jak „moralny dowód” istnienia Boga. I właśnie o tym, nawet jeśli bardzo niepoprawnie, mowa jest w powieści Bułhakowa. W Krytyce czystego rozumu, w dziedzinie poznania teoretycznego, o Bogu jako o idei transcendentalnej pisał Kant przypuszczalnie tylko z perspektywy regulatywnego zastosowania idei, tzn. w taki sposób, jak gdyby Bóg istniał, chociaż tego rodzaju istnienie (tak samo jak nieistnienie) pozostaje dla nas zasadniczo nie do udowodnienia. W Krytyce praktycznego rozumu Kant, rozwijając już wcześniej wypowiedziane myśli, sformułował swoją teorię postulatów praktycznego rozumu, przez które rozumie podmiotowe żądania

${ }^{30} \mathrm{KrV}$ : B XXXIV [wyróżnienia w tekście zgodne z wydaniem polskim]. Do swoich przyszłych adwersarzy, oburzonych krytyką dowodów istnienia Boga w dziedzinie teoretycznej, Kant zwrócił się w następujący sposób: „Wszelkie zatem lamenty i bezsilne złorzeczenia z powodu rzekomego bluźnierstwa, jakim miałoby być wątpienie w słuszność łańcucha waszych wniosków [Schlußkette], są czczą bufonadą, która pragnęłaby, żeby [wszelkie] wątpienie wyraźnie przeciwstawione waszej argumentacji, uznane było za podawanie w wątpliwość uświęconej prawdy, a to po to, byście pod tym płaszczykiem przemycili płytkość owej argumentacji." KU: V 480.

${ }^{31} \mathrm{KrV}: \mathrm{B}$ 769-770/A 741-742.

${ }^{32} \mathrm{KrV}: \mathrm{B} 770 / \mathrm{A} 742$.

${ }^{33} \mathrm{KrV}$ : B 781/A 753. 
uznania czegoś za obiektywne ze względu na nasze potrzeby: „Postulaty te nie są teoretycznymi dogmatami, lecz koniecznymi założeniami [poczynionymi] ze względów praktycznych" ${ }^{34}$. Na równi z wolnością i nieśmiertelnością duszy postulatem $\mathrm{w}$ tym sensie jest również istnienie Boga, które uznajemy opierając się na moralnej konieczności. Jednakże ta „moralna [moralische] konieczność jest koniecznością podmiotową, tj. potrzebą, a nie [koniecznością - T. K.] o b i ekt y w n ą, tj. samym obowiązkiem, ponieważ nie może istnieć obowiązek przyjmowania istnienia rzeczy (to bowiem dotyczy tylko teoretycznego użycia rozumu)" ${ }^{35}$. Albo - jak to zostało sformułowane w notatkach filozofa - ,istnienia Boga się nie dowodzi, ale się je postuluje; może ono więc służyć tylko do tego, by rozum był zmuszony postulować jego

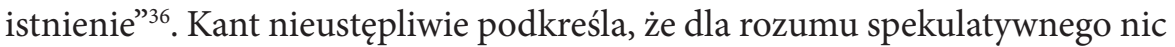
się przez to nie zmienia, ponieważ ma on jedynie na myśli „ro z s z e r z e n i e czystego rozumu w praktycznym zamiarze, nie rozszerzając przez to zarazem jego poznania jako rozumu spekulatywnego" ${ }^{37}$. Jeszcze w pismach przedkrytycznych Kant podkreśla myśl, że dla człowieka „Jest czymś ze wszech miar koniecznym przekonać się o istnieniu Boga, ale nie aż tak znowu koniecznym, ażeby go dowodzić”38. Co więcej, podobne dowody w dziedzinie teoretycznej dojrzały Kant nazywa czasami mędrkowaniem. Gdyby jednak okazały się pomyślne, to doprowadziłyby do zguby autonomię ludzkiej woli i spowodowałyby utratę przez człowieka wolności, przekształcając go w mechaniczną lalkę, a „większość czynów zgodnych z prawem zachodziłaby z obawy, zaś niewielka tylko część $\mathrm{z}$ nadziei, lecz żaden nie zachodziłby z obowiązku, moralna [moralischer] zaś wartość czynów, od której przecież w oczach najwyższej Mądrości wyłącznie zależy wartość osoby, a nawet wartość świata, zupełnie by nie istniała"39.

Mimo to, nie zważając na wszystko, co zostało wyżej powiedziane, Kant w Krytyce władzy sądzenia wprowadza pojęcie "moralnego dowodu” istnienia Boga, a wraz z nim także zamęt we własnym stanowisku. Nowe pojęcie niczego nie zmienia $\mathrm{w}$ tym, co zostało powiedziane już w Krytyce czyste-

\footnotetext{
${ }^{34} \mathrm{KpV}$ : V 132 [cytuje według: I. Kant, Krytyka praktycznego rozumu, tłum. B. Bornstein, oprac. M. Żelazny, [w:] tenże, Dzieła zebrane, t. 3, Toruń 2012].

${ }^{35} \mathrm{KpV}: \mathrm{V} 125$.

${ }^{36}$ AA Bd. XIX, s. 637. Refl. 8092.

${ }^{37} \mathrm{KpV}: \mathrm{V} 134$.

${ }^{38}$ I. Kant, Jedyna możliwa podstawa dowodu na istnienie Boga, tłum. Translatorium Filozofii Niemieckiej IF UMK, [w:] tenże, Dzieła zebrane, t. 1, Toruń 2010, s. 614.

${ }^{39} \mathrm{KpV}: \mathrm{V} 147$.
} 
go rozumu i w Krytyce praktycznego rozumu, ale z niezrozumiałych powodów wszyscy używają sformułowania „dowód”, w odniesieniu do czegoś, co dowodem w ścisłym tego słowa znaczeniu nie jest. Przy czym filozof stosuje to rozumowanie wobec dwóch postulatów praktycznego rozumu, a mianowicie wobec postulatu istnienia Boga i nieśmiertelności duszy: „moralny dowód stwierdza nie to, że dusza będzie żyć w przyszłości, lecz to, że pozbawiony uprzedzeń człowiek nie może uniknąć takiego założenia i uważać je, przynajmniej, za możliwe" ${ }^{40}$. Prawdobodobnie, na terminologię Kanta wpłynął Johann Georg Sulzer (1720-1779) ${ }^{41}$. Właśnie jego bowiem wspomina filozof w owym pytaniu zarówno w Krytyce czystego rozumu $u^{42}$, jak i w wykładach.

W wykładach z metafizyki z połowy lat siedemdziesiątych XVIII wieku stanowisko Kanta przedstawia się następująco. W rozdziale $O$ stanie duszy po śmierci przedstawione zostały rozmaite warianty tego, co Kant nazywa „moralnym” albo „teologiczno-moralnym” dowodem, "ponieważ postuluje on poznanie Boga” ${ }^{\prime 3}$. Ten „moralny dowód [...] jest praktycznie w pełni wystarczający dla wiary w przyszły stan [duszy]”"44, jest „dla wiary wystarczającym

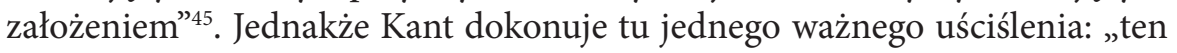
moralny dowód praktycznie jest wystarczający w przypadku człowieka uczciwego; natomiast człowiek nieuczciwy odrzuca nie tylko [moralne] prawo, ale i [istnienie] jego twórcy” ${ }^{46}$. W rozdziale „O czystej teologii racjonalnej”,

${ }^{40}$ AA Bd XVIII, s. 194, Refl. 5475. Por. także o „moralnym dowodzie” przyszłego życia: AA Bd. XVII, Berlin 1926, s. 714, Refl. 761. Ponadto Kant dostrzegał możliwość istnienia wariantów moralnego dowodu nieśmiertelności duszy: por. AA Bd XVIII, s. 192, Refl. 5472.

${ }^{41}$ Por. AA Bd. XVIII, s. 85, Refl. 5091; I. Kant, Vorlesungen über Metaphysik. Zum Drucke befördert von dem Herausgeber der Kantischen Vorlesungen über die philosophische Religionslehre [K. H. L. Pölitz]. Nebst einer Einleitung, welche eine kurze Übersicht der wichtigsten Veränderungen der Metaphysik seit Kant enthält, Erfurt 1821, s. 238. W uwagach do rosyjskiego wydania Krytyki czystego rozumu znalazła się przykra niedokładność. Do roku 1764 Sulzer nie mógł dysponować rozprawą pod nazwą O niektórych możliwych dowodach istnienia Boga (por. Uwagi [w:] Krytyka czystego rozumu, s. 561). Źródłem tego błędu była nieprawidłowa interpretacja następującej frazy z listu Lamberta do Kanta: „rok temu pan profesor Sulzer pokazał mi Pańskie możliwe dowody istnienia Boga" (J. H. Lambert, Brief an I. Kant vom 13. November 1765, [w:] AA Bd. X, s. 51, nr 33). Innymi słowy Lambert zakomunikował tu Kantowi o tym, że za pośrednictwem Sulzera zapoznał się z Kantowskim traktatem z 1763 roku.

${ }^{42}$ [Por. KrV: B 769-770/A 741-742].

${ }^{43}$ I. Kant, Vorlesungen über die Metaphysik, s. 239.

${ }^{44}$ Tamże, s. 241.

${ }^{45}$ Tamże, s. 243.

46 Tamże, s. 244. 
w podrozdziale zatytułowanym „O teologii transcendentalnej”, będącej „poznaniem praistoty za pomocą tylko pojęć czystego rozumu”", Kant wyróżnia cztery podobne pojęcia ${ }^{48}$, które następnie będą odpowiadać czterem dowodom istnienia Boga. Wykłady te zasługują na uwagę również dlatego, że Kant wymienia w nich myślicieli, których rozważania stanowią dla niego punkt wyjścia w tej kwestii. Oprócz wspomnianego Sulzera, są nimi także Descartes i Wolff ${ }^{49}$.

U podstaw teologii transcendentalnej leży tak zwany transcendentalny dowód istnienia Boga, w innych wypadkach nazywany przez Kanta dowodem ontologicznym. Jednakże dla pełni obrazu „powinny zostać przywołane jeszcze pozostałe dowody, a mianowicie kosmologiczny, fizyko-teologiczny i moralny; tym samym mogą zostać rozpatrzone wszystkie cztery rodzaje dowodów, a nie tak, jak wierzył Sulzer: być może, zostanie odnaleziony jeszcze jeden, który mógłby stanowić rzeczywiście oryginalny dowód istnienia Boga" ${ }^{50}$. W ten sposób, w wykładach, w odróżnieniu od Krytyki czystego rozumu, u samego Kanta obecne są cztery rodzaje dowodów: trzy dowody teologii naturalnej (filozof zalicza do nich także dowód transcendentalny teologii transcendentalnej), a także jeszcze jeden, czwarty rodzaj, wykraczający już jednak poza jej granice. Pierwsze trzy dowody - „transcendentalny, kosmologiczny i fizyko-teologiczny - [to dowody, w których] istota dowodzenia opiera się na zasadach rozumu teoretycznego, w przypadku których istnienie Boga traktowane jest jako niezbędna przesłanka naszego teoretycznego użycia rozumu. Jest jednak jeszcze czwarty rodzaj dowodu, w przypadku którego istnienie Boga rozpatruje się jako niezbędną przesłankę praktycznego użycia rozumu; ten właśnie dowód jest dowodem moralnym. Zawarta jest w nas potrzeba, by w zgodności z praktycznym użyciem rozumu, zakładać istnienie Boga" ${ }^{51}$.

\footnotetext{
${ }^{47}$ Tamże, s. 273.

${ }^{48}$ Por. tamże, s. 274.

${ }^{49}$ Por. tamże, s. 280, 282, 284. W Krytyce władzy sądzenia Kant wspomina ponadto Hermanna Samuela Reimarusa (1694-1768); KU: V 476.

${ }^{50}$ I. Kant, Vorlesungen über die Metaphysik, s. 283. Najwyraźniej Kant ma na myśli oryginalne rozważania Sulzera zawarte w następującym artykule: J. G. Sulzer, Gedanken über einige Eigenschaften der Seele, in so fern się mit den Eigenschaften der Materie eine Aenlichkeiten haben, zur Prüfung des Systems des Materialismus, [w:] tenże, Vermischte philosophische Schriften aus den Jahrbüchern der Akademie der Wissenschaften zu Berlin gesammelt, Leipzig 1783, s. 349.

${ }^{51}$ I. Kant, Vorlesungen über die Metaphysik, s. 288-289. Refl. 6454: „Moralna potrzeba przyjęcia najwyższego moralnego dobra..... AA Bd. XVIII, s. 725.
} 
W jakiej mierze dowód moralny jest dowodem? Jeśli za wzór brać dowody z dziedziny teoretycznej, to dowód moralny dowodem nie jest: „Dowód dogmatyczny jest dowodem spekulatywnym opartym na racjach logicznych. Jednakże takiego w pełni wartościowego dowodu nie jesteśmy w stanie dostarczyć, ponieważ rozum nie ma wystarczających podstaw, by udowodnić to a priori; natomiast opierając się na doświadczeniu nie potrafimy osiągnąć tego, czego pragniemy, a mianowicie określonego pojęcia o wszystkich właściwościach istoty tego rodzaju” ${ }^{2}$. Kant podkreśla: „Istnienie Boga może zostać udowodnione nie bezpośrednio, lecz tylko pośrednio; nie mogę go zademonstrować innemu [człowiekowi]. Jeśli jednak on pragnie udowodnić coś przeciwnego, to mogę sprowadzić jego pogląd do logicznego i praktycznego absurdu" 53 .

Kant twierdzi, że „moralny dowód wnika w najgłębsze źródło [ludzkiego] postępowania i z perspektywy praktycznej jest najdoskonalszym i najbardziej kompletnym dowodem. Bóg staje się tu przedmiotem wiary i nikt nie jest w stanie jej wykorzenić. Wszystkie spekulatywne kontrargumenty okazują się tu bezsilne, bo jestem niezachwianie przekonany o tym [że Bóg istnieje]. Chociaż nie mogę udowodnić tego, że Bóg jawi mi się jako karzący albo nagradzający [sędzia], to również nikt nie może udowodnić niczego przeciwnego i ta niezbędna przesłanka jest już wystarczającą podstawą dla przyjęcia Boga. Za pomocą dowodu moralnego nie tylko upewniamy się o istnieniu najświętszej istoty, ale i stajemy się dzięki temu także lepsi. Dowód ten nie tylko wychodzi od pewnych praktycznych założeń, ale równocześnie wywiera także praktyczne oddziaływanie. Dowód ten należy z całą mocą rekomendować i wprowadzać go jako element kształcenia młodych ludzi, bowiem moralność jest czymś najważniejszym spośród wszystkich innych spraw"54. Tym samym staje się zrozumiałe, że i w tym punkcie Heine kolejny raz popełnił błąd; Kant adresował dowód moralny nie do swojego starego służącego, ale do młodzieży. Kolejne nieporozumienie Heinego stanie się jasne, jeśli zwrócimy uwagę na to, przeciwko komu - według Kanta - kierowane są dowody istnienia Boga. Transcendentalne albo ontologiczne dowody - kierowane są przeciwko ateistom, natomiast dowody teologii naturalnej (kosmologiczne i fizyko-teologiczne) - przeciwko deistom, zaś dowód teologii moralnej55

\footnotetext{
${ }^{52}$ I. Kant, Vorlesungen über die Metaphysik, s. 297.

${ }^{53}$ Tamże, s. 292.

${ }^{54}$ Tamże, s. 293-294.

${ }^{55}$ Refl. 6214: „Teologia moralna, nie zaś teologiczna moralność. W tej drugiej bowiem moralność wynika z istnienia Boga, w pierwszej zaś istnienie oraz rozumienie Boga określone są za
} 
(dowód moralny) - „contra Ethnicos” ${ }^{56}$, czyli przeciwko tym, którzy uznawali najwyższą istotę, ale nie uważali jej za świętą, wszechdobrą itp. Heine zapewnia, że krytyką dowodów istnienia Boga w Krytyce czystego rozumu (ontologicznego albo transcendentalnego, kosmologicznego i fizyko-teologicznego) Kant położył kres „deizmowi”.

W Krytyce władzy sadzenia ${ }^{57}$ Kant przystępuje do "moralnego dowodu istnienia Boga" po rozpatrzeniu fizykoteologii i etykoteologii ( $\$ \$ 85-86)$. Uzasadnia tam przyjęcie moralnej przyczyny świata albo stwórcy świata tym, że bez tego założenia nie można przyjmować ostatecznego celu w zgodności z prawem moralnym. Jednakże i w tym przypadku Kant wywołuje pewien zamęt: $\mathrm{z}$ jednej strony bowiem zapewnia, że dowodowi moralnemu „łatwo można nadać formę logicznej precyzji” "58 a z drugiej strony, podkreśla, że „moralny [moralische] argument nie ma dostarczyć ob i ekt y wn i e ważnego dowodu istnienia Boga, nie ma wątpiącemu udowodnić, że Bóg istnieje, lecz jedynie to, że jeśli chce pod względem moralnym [moralisch] myśleć konsekwentnie, to m u s i zgodę na tę tezę włączyć do maksym swego praktycznego rozumu. - Nie ma też przez to być powiedziane, że do moralności [Sittlichkeit] konieczne jest przyjęcie szczęśliwości wszystkich istot rozumnych świata stosownie do ich moralności [Moralität], lecz że dzięki ni ej jest to konieczne. Jest to zatem podmi otowo, dla istot moralnych [moralische], wystarczający argument" ${ }^{\prime \prime}$. Czasami argumentacja Kanta przypomina słynny zakład Pascala. Niemiecki filozof nie udowadnia istnienia Boga, ale pokazuje niesprzeczność w praktycznym stosunku do podobnego założenia, następnie zaś przytacza argumenty na korzyść tego, jak skutecznie urzeczywistnić to założenie. Jednocześnie dopuszcza możliwość przyjęcia moralnego prawa bez założenia istnienia Boga, chociaż podobne stanowisko wydaje mu się dziwaczne i ułomne.

Znaczenie wątpliwości, czy mamy $\mathrm{w}$ tym przypadku do czynienia z dowodem, czy też nie, Kant wyraźnie bagatelizuje ( $\$ 88)$ : „Rzeczywistość najwyższego moralnie [moralisch] prawodawczego stwórcy jest zatem dosta-

pośrednictwem moralności.” AA Bd. XVIII, s. 500. Por. także KU $₫ 85$.

${ }^{56}$ I. Kant, Vorlesungen über die Metaphysik, s. 296.

${ }^{57}$ Poza tą rozprawą, pojęcie „dowodu moralnego" w wydanych przez filozofa pracach występuje tylko w Sporze fakultetów; por. SF: A 124 (fragmentu tego brakuje w przekładzie rosyjskim). Por. także na temat dowodu moralnego: E. G. Dominici, Brief an I. Kant vom 28. Juli 1796, [w:] AA Bd. XII, s. 88-90, nr 711; AA Bd. XVIII, s. 477-478, Refl. 6173.

${ }^{58} \mathrm{KU}: \mathrm{V} 450, \S 87$.

${ }^{59} \mathrm{KU}: \mathrm{V} 450$, przyp. $\$ 87$. 
tecznie uzasadniona [dargethan] tylko dl a praktycznego u żytku naszego rozumu, lecz w teoretycznym [użyciu rozumu] nie przesądza to jeszcze niczego o istnieniu [Dasein] tegoż [stwórcy]"60.

Nazywając dowód moralny „argumentem moralnym” ( $\$ 89)$, co jest wyrażeniem znacznie bardziej precyzyjnym, Kant wskazuje na inne płynące z niego korzyści. Możliwość jedynie moralnej argumentacji na rzecz istnienia Boga i niemożliwość dowodów teoretycznych, a nawet „[p]rzyczyna, dla której zawodzi taka próba udowodnienia Boga oraz nieśmiertelności na drodze czysto teoretycznej"61, tzn. ograniczenie rozumu w odniesieniu do nadzmysłowych warunków jego praktycznego zastosowania, zabezpiecza nas przed przekształceniem teologii w teozofię, demonologię i teurgię albo bałwochwalstwo. W tym właśnie punkcie Kant dostrzegał zasługę przeprowadzonej przez siebie krytyki. Co więcej, niemożliwość teoretycznego dowodu istnienia Boga przynosi jeszcze jeden dobroczynny skutek: moralność okazuje się wolna od konieczności zgadzania się z teologią. To zaś, w konsekwencji, czyni niemożliwym wprowadzenie „na miejsce wewnętrznego koniecznego prawodawstwa rozumu [...] jakie[goś] zewnętrzne[go], samowolne[go] [willkürliche] prawodawstw[a] najwyższej istoty" ${ }^{2}$; uniezależnia moralne nakazy od wszelkich braków w znajomości natury Boga; ratuje religię przed wypaczeniem i chroni jej moralność. Innymi słowy, gdyby religia mogła zostać oparta na trwałych teoretycznych podstawach, wówczas nasze pojęcie o obowiązku zyskałoby „znamię przymusu oraz wymuszonej uległości. Jeśli natomiast głębokie poszanowanie prawa moralnego [das sittliche Gesetz] ukazuje nam w sposób wolny, zgodnie $\mathrm{z}$ nakazem naszego własnego rozumu, ostateczny cel naszego powołania, to do naszych perspektyw moralnych [moralischen] włączamy przyczynę harmonizującą z tym celem oraz jego realizacją. Czynimy to zaś z prawdziwą czcią, która jest czymś różnym od patologicznego lęku. I chętnie się jej podporządkowujemy"63.

Kant $\mathrm{w}$ Krytyce władzy sądzenia wielokrotnie podkreśla podstawowe wnioski sformułowane już w Krytyce czystego rozumu i Krytyce praktycznego rozumu, które mimo to $\mathrm{w}$ wyniku jego rozważań na temat argumentu moralnego ani trochę nie ucierpiały, a mianowicie twierdzi, że „...w aspekcie teoretycznym dla rozumu ludzkiego bezwzględnie nie jest możliwy żaden do-

\footnotetext{
${ }^{60} \mathrm{KU}: \mathrm{V} 456, \S 88$. Por. Refl. 6451: „Nie jest to dowód obiektywnie wystarczający, ale podmiotowo-praktycznie wystarczający dowód moralny" AA Bd. XVIII, s. 723.

${ }^{61} \mathrm{KU}: \mathrm{V} 474, \S 91$.

${ }^{62} \mathrm{KU}: \mathrm{V} 460, \S 89$.

${ }^{63} \mathrm{KU}: \mathrm{V}$ 481-482.
} 
wód istnienia [Dasein] praistoty jako bóstwa, albo duszy jako nieśmiertelnego ducha, który [to dowód] w najmniejszym choćby stopniu mógłby spowodować uznanie tego za prawdziwe” ${ }^{64}$. Kant wyjaśnia, że „[z]dziwienie czy też rzekoma sprzeczność postulowanej tu możliwości teologii z tym, co w krytyce spekulatywnego rozumu powiedziano o kategoriach - polegające na tym, że kategorie mogą dać [hervorbringern] poznanie tylko przy zastosowaniu do przedmiotów zmysłowych, nigdy natomiast do tego, co nadzmysłowe - zanika, gdy widzimy, że używamy ich tutaj do poznania Boga, lecz nie w zamiarze teoretycznym (zgodnie z tym, czym jest niezbadana dla nas natura [Boga] sama w sobie), tylko wyłącznie praktycznym" ${ }^{65}$. Zarówno istnienie Boga jak i nieśmiertelność duszy nazywa on "rze cza mi wi a ry" ${ }^{66}$. Jednakże owe "rzeczy wi ary” wyraźnie odróżnia od „artykułów wi ary”, podzielanie bowiem przekonania o prawdziwości tych ostatnich „może być narzucone jako obowiązek”, podczas gdy te pierwsze są „swobodnym uznawaniem czegoś za prawdę. I tylko jako takie [...] daje się ono pogodzić z moralno-

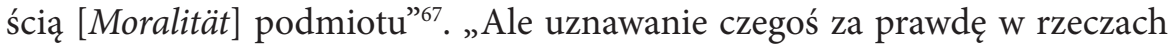
wiary [Glaubenssachen] jest uznawaniem za prawdę tylko w zamiarze czysto praktycznym, tzn. jest wiarą moralną [moralischer Glaube], która niczego nie dowodzi dla teoretycznego, lecz tylko dla praktycznego czystego poznania rozumowego, nastawionego na spełnianie obowiązków i bynajmniej nie rozszerzającego spekulacji ani praktycznych reguł, kierującej się podstawową zasadą [Princip] samolubstwa mądrości. O ile najwyższa podstawowa zasada [Princip] wszelkich praw moralnych [Sittengesetze] jest postulatem, to wraz z nim postulowana jest zarazem możliwość jej najwyższego obiektu, a tym samym warunek, pod jakim możliwość tę możemy pomyśleć. Poznanie [owej możliwości] nie staje się przez to w teoretycznym sposobie poznania ani wiedzą, ani domniemaniem (odnoszącym się do istnienia [Dasein] i właściwości tych warunków), lecz jedynie przypuszczeniem praktycznym i do tego nakazanym w odniesieniu do moralnego [moralischen] użytku naszego rozumu"68.

Precyzując, jakie miejsce argument moralny zajmuje wśród innych argumentów przemawiających za istnieniem Boga, Kant podkreśla, że często jest on w oczywisty sposób mylony z dowodem fizyko-teleologicznym, który jako jedyny spośród wszystkich dowodów teoretycznych ma pewne

\footnotetext{
${ }^{64} \mathrm{KU}: \mathrm{V} 466, \S 90$.

${ }^{65} \mathrm{KU}: \mathrm{V} 482$.

${ }^{66} \mathrm{KU}: \mathrm{V} 467, \S 91$.

${ }^{67} \mathrm{KU}: \mathrm{V} 469$, przyp. $\$ 91$.

${ }^{68} \mathrm{KU}: \mathrm{V} 470, \S 91$.
} 
znaczenie dla pospolitego ludzkiego rozsądku. Jednak, ściśle mówiąc, „moralna racja dowodowa [der moralische Beweisgrund] istnienia Boga [Dasein] nie tylko u zupełni a fizyczno-teleologiczną rację dowodową, [czyniąc ją] pełnym dowodem, ale jest dowodem odrębnym, który r e k o m p e n su j e $[$ erset $z t]$ brak mocy przekonywającej tamtej racji dowodowej" ${ }^{\prime 9}$. Ale pomimo wszystkich ograniczeń i zastrzeżeń Kanta, a także uwzględniając historyczny kontekst, i tak pozostaje do końca niezrozumiałe, dlaczego była tu mowa właśnie o moralnym "dowodzie”, a nie chociażby o „argumencie”, skoro Kantowi chodziło o dowód „istnienia [Dasein] Boga tylko jako rzeczy wiary [Glaubenssache] dla praktycznie czystego rozumu”,", "tylko z praktycznego, ale przecież nieodpartego punktu widzenia"71, a sam „dowód moralny" traktowano ,jako niezbędną hipotezę ze względu na spekulatywne i praktyczne zainteresowanie"72 ludzkiego rozumu. Terminologia Kantowska pod wieloma względami jest winna błędnych interpretacji jego filozofii, co widać także na przykładzie Mistrza i Małgorzaty. Na grzechy samego Kanta nakładają się tu dodatkowo naciągane interpretacje Heinego.

Dlaczego Kant określony został w powieści Bułhakowa jako „nieokiełznany"? Nie potrafię odpowiedzieć na to pytanie. To, że filozofa nazwano w niej „staruszkiem” mieści się w pewnej tradycji, która nie budzi wątpliwości. W przypadku Bułhakowa nawiązanie do zaawansowanego wieku niemieckiego myśliciela nie okazuje się jakąś formą charakterystyki martwoty jego filozofii, jak to się już utarło interpretować. Jest w pełni zrozumiałe, dlaczego w ten sposób wypowiadali się o Kancie młodsi od niego, współcześni mu myśliciele. Wystarczy tu wspomnieć Goethego albo Schillera ${ }^{73}$, którzy byli młodsi od królewieckiego filozofa o 25-35 lat. Z filozoficznego, a także z historycznego punktu widzenia wydawał się im człowiekiem należącym do zupełnie innej epoki. Dlaczego jednak w taki sposób mówi o nim Woland? „Burzyciel” wszystkich dowodów istnienia Boga, świeżo upieczony autor Krytyki czystego rozumu miał już 57 lat. Bułhakow, autor powieści Mistrz i Małgorzata, nad którą pracował jeszcze dłużej niż Kant nad Krytyką czystego rozumu, miał lat 48.

\footnotetext{
${ }^{69} \mathrm{KU}: \mathrm{V} 478$.

${ }^{70} \mathrm{KU}: \mathrm{V} 475$.

${ }^{71} \mathrm{KU}: \mathrm{V} 478$.

${ }^{72}$ AA Bd. XVIII, s. 502, Refl. 6214.

${ }^{73}$ Por. np.: I. V. Gëte, Pis'mo F. Šilleru ot 28 iûlâ 1798 g., [w:] I. V. Gëte, F. Šiller, Perepiska (V 2-h t.), t. 2, nr 489, s. 123.
} 
Uwaga Bułhakowa o rozmowie Wolanda $\mathrm{z}$ Kantem podczas śniadania wydaje się przykrą pomyłką pisarza; rzecz w tym, że Kant praktycznie całe swoje dojrzałe życie (jako „profesor”) nigdy nie jadł śniadania. Zamiast tego każdego ranka wypalał fajkę tytoniu i wypijał jedną, albo dwie filiżanki słabej herbaty. Ale nawet podczas tego zajęcia, które tylko od biedy można by nazwać śniadaniem, zawsze przebywał $\mathrm{w}$ samotności, zajęty własnymi myślami. Także z innego powodu okoliczności byłyby wyraźnie nieodpowiednie dla gości - wszystko to działo się o godzinie piątej rano ${ }^{74}$. Gdyby więc Bułhakow zamienił „najosobliwsze śniadanie u zmarłego filozofa Kanta” na obiad, to trafiłby w sedno.

Przełożył Tomasz Kupś

${ }^{74}$ Por. R. B. Jachmann, Immanuel Kant geschildert in Briefen an einen Freund, s. 166; E. A. Ch. Wasianski, Immanuel Kant in seinen letzten Lebensjahren, s. 204. 